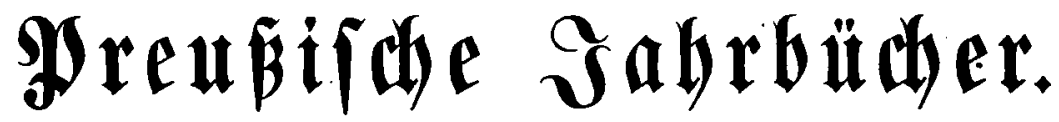

bexa

beiurid von Zreitidfe.

Sed $\mathfrak{b} \mathfrak{u}$ biergigiter $\mathfrak{B} \mathfrak{a} \mathfrak{n}$.

\section{Berlin, 1880.}

Drữ unb Berlag von (S). Reimer. 
